\title{
CORRELAÇÃO ENTRE O DIÂMETRO E A DENSIDADE DAS FIBRAS DE EUCALIPTO UTILIZANDO O MÉTODO DE WEIBULL*
}

\section{Resumo}

\author{
Caroline Gomes de Oliveira ${ }^{1}$ \\ Anna Carolina Cerqueira Neves ${ }^{2}$ \\ Gilson Vieira Fernandes ${ }^{3}$ \\ Marcus Vinícius Fonseca Ferreira 4 \\ Frederico Muylaert Margem ${ }^{5}$ \\ Sérgio Neves Monteiro ${ }^{6}$
}

As fibras lignocelulósicas representam vantagens econômicas, técnicas e ambientais em comparação com as fibras sintéticas, como fibra de vidro por exemplo, quando se considera as alternativas de reforço aos compósitos. A fibra natural usada no presente trabalho é a fibra de eucalipto, que é largamente cultivada em território brasileiro. Este trabalho tem como objetivo avaliar uma análise estatística da correlação entre o diâmetro e a densidade da fibra de eucalipto. Para isso, foi aplicado o método de Weibull. O diâmetro foi obtido por meio de medições em projetor de perfil, enquanto a densidade utilizou determinações precisas da massa e do volume de fibras. Os resultados revelaram uma dependência inversa entre o diâmetro da fibra de eucalipto e sua densidade.

Palavras-chave:Fibra de eucalipto; Método de Weibull; Diâmetro; Densidade.

\section{CORRELATION BETWEEN THE DIAMETER AND THE DENSITY OF EUCALYPTUS FIBER USING THE WEIBULL ANALYSIS}

\section{Abstract}

The lignocellulosic fibers represent economical, technical and environmental advantages regarding alternative materials as composites reinforcement compared to synthetic ones, such as the glass fiber. The natural fiber used in this present work is the eucalyptus fiber, which is largely cultivated in Brazilian territory. This work aims to evaluate a statistical analysis of the correlation between the diameter and the density of eucalyptus fiber. For this, the Weibull methodology was performed. The diameter was obtained by profile projector measurements, while the density used precise determinations of the fibers mass and volume. The results revealed an inverse dependence between the eucalyptus fiber diameter and its density.

Keywords: Eucalyptus fiber; Weibull methodology; Diameter; Density.

1 Metallurgical and Materials Engineering, Undergraduation student, Laboratory of Advanced Materials, State University of the Northern Rio de Janeiro Darcy Ribeiro, Campos dos Goytacazes, RJ - Brazil

2 Metallurgical and Materials Engineering, Undergraduation Student, Laboratory of Advanced Materials, State University of the Northern Rio de Janeiro Darcy Ribeiro, Campos dos Goytacazes, RJ - Brazil

3 Metallurgical and Materials Engineering, Undergraduation student, Laboratory of Advanced Materials, State University of the Northern Rio de Janeiro Darcy Ribeiro, Campos dos Goytacazes, RJ - Brazil

4 Metallurgical and Materials Engineering, Undergraduation student, Laboratory of Advanced Materials, State University of the Northern Rio de Janeiro Darcy Ribeiro, Campos dos Goytacazes, RJ - Brazil

5 Metallurgical and Materials Engineering, D. Sc., Assistant Professor, Center of Science and Engineering, Redentor University, Itaperuna, RJ - Brazil.

$6 \quad$ PhD Metallurgical and Materials Engineering, PhD, Main Professor, Laboratory of Materials and Metallurgy, Military Institute of Technology, Rio de Janeiro, RJ - Brazil. 


\section{INTRODUCTION}

According to Kalia, Kaith e Kaurs [1] cellulose-based fibers are being used due to its "green" image. Instead of glass fibers, widely used in modern technology, the lignocellulosic fibers are renewable and can be incinerated at the end of material useful life without the addition of air pollution, since the amount of $\mathrm{CO}_{2}$ liberated during the incineration is negligible compared to the amount absorbed by the plant throughout its life. Even if the industrial processing of an equivalent release of $\mathrm{CO}_{2}$ is added, the lignocellulosic fiber can be considered neutral with respect to the emission of gases responsible for global warming [2].

The use of lignocellulosic fiber as packaging, textile, construction and automobilist is growing. One of its most promising applications is as reinforcement for polymer composites. In fact, a considerable number of publications[3-8] have been devoted to lignocellulosic fiber as reinforcement in polymer composites. In particular, in industrial applications are already on the market, mostly in automotive industry [9-12].

Despite environmental benefits and economic advantages, technical and social aspects of lignocellulosic fibers, as the deficiencies, dimensional heterogeneity and low interfacial adhesion with polymers typically used as composite matrix [3-7]. Another feature that can significantly affect the properties of lignocellulosic fiber is an appreciable dimensions transverse effector cross-sectional area [3].

It is worth noting that the cultivation of natural fibers can also have a positive social impact. It contributes for the non-food agriculture, working as a source of income, especially in developing countries [13]. The Eucalyptus plant is cultivated extensively in all Brazilian territory, which adds further advantages to this fiber: its cultivation is source of income for many families in the rural areas, its abundant and even cheaper than non-native fibers, because it can be eliminated costs with importation.

The objective of this work is to evaluate the medium and characteristic density of the Eucalyptus fiber, analyzing the density and the influence of the diameter on this property.

\section{MATERIAIS E MÉTODOS}

The basic material used in this work was untreated eucalyptus fibers. Statistical analysis were performed on one hundred fibers randomly removed from the asreceived the lot. These fibers were then measured in five different points along the length, and were $90^{\circ}$ rotated to be measured again, assuming a ellipitcal cylindric structure for the fibers. The rotation guarantees the correct values of the mean diameter for each fiber. Fig. 1 shows the histogram for the distribution of eucalyptus fibers diameters by considering 6 diameter intervals. 


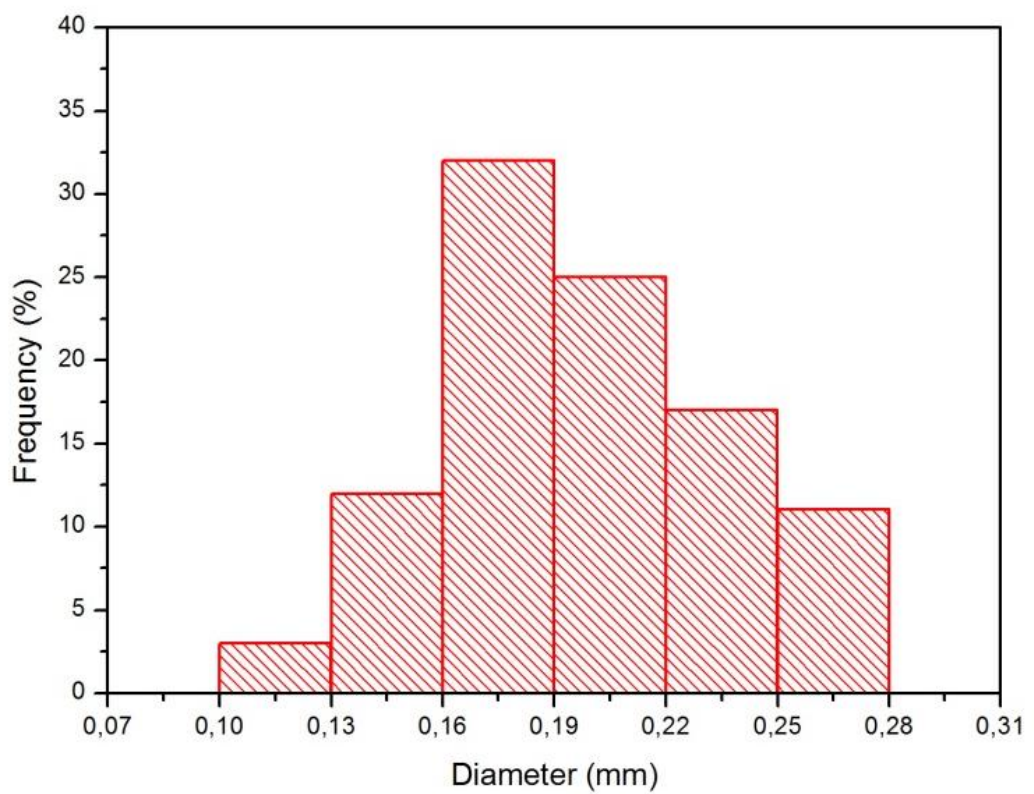

Figure 1. Histogram of the frequency of Eucalyptus fibers for each diameter interval.

After the statistical analysis, each diameter interval was completed with 20 or more fibers for density measurements that would allow a Weibull analysis. Tab. 1 presents the number of Eucalyptus fibers measured in each diameter interval.

Table 1. Diameter intervals and number of fibers obtained for density measurements.

\begin{tabular}{|c|c|}
\hline Diameter interval $(\mathbf{m m})$ & Number of fibers \\
\hline $0.10<\mathrm{d}<0.13$ & 03 \\
$0.13<\mathrm{d}<0.16$ & 12 \\
$0.16<\mathrm{d}<0.19$ & 32 \\
$0.19<\mathrm{d}<0.22$ & 25 \\
$0.22<\mathrm{d}<0.25$ & 18 \\
$0.25<\mathrm{d}<0.28$ & 10 \\
\hline
\end{tabular}
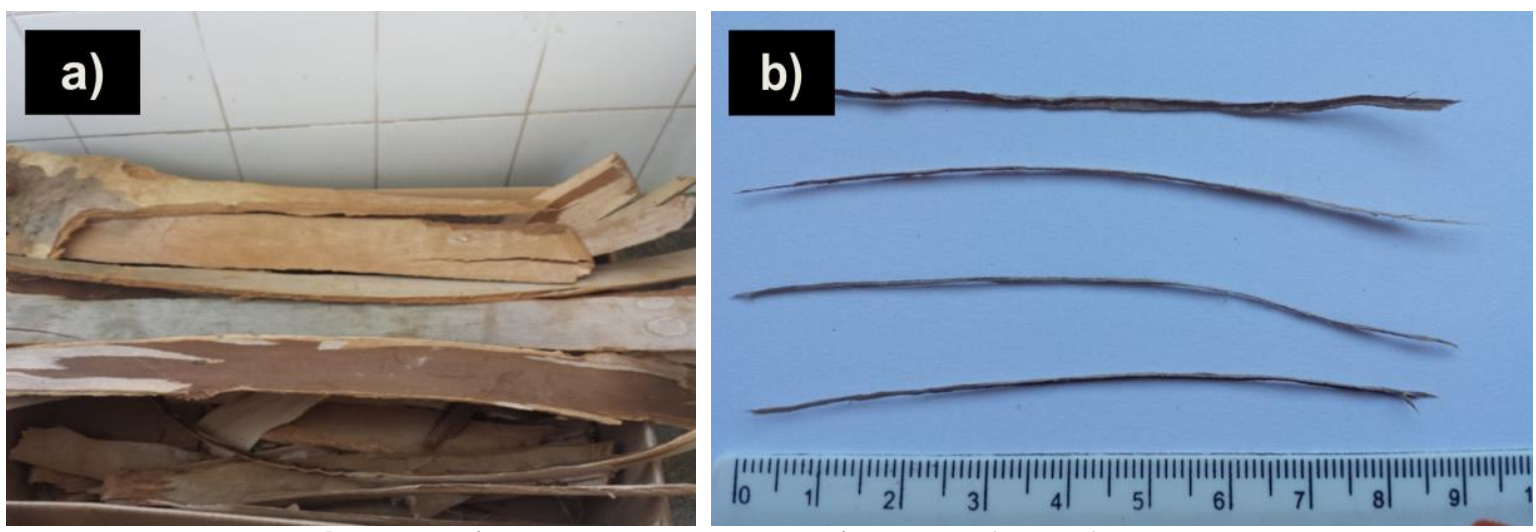

Figure 2. a) Eucalyptus bark and b) Fibers after defibrillation 
For each interval of equivalent diameter in Tab. 1, the selected eucalyptus fibers had their diameter and length individually measured using a profile projector Nikon 6C and each fiber was weighed in a precision balance. The density of each fiber was then calculated considering a cylindrical volume of the fibers, by the relationship:

$$
\rho=\frac{4 m}{\pi d^{2} l}
$$

Where: $\mathrm{m}$ - mass; $\mathrm{d}$ - diameter; I - length; $\rho$ - density.

\section{RESULTS AND DISCUSSION}

Based on the values of weight and volume, an average value of density was obtained for each fiber. These values were statistically analyzed by means of the Weibull method for at least 20 fibers associated with each of the six diameter intervals. The Weibull Analysis program provided the probability plots of reliability vs. location parameter shown in Fig. 3 for all diameter intervals.

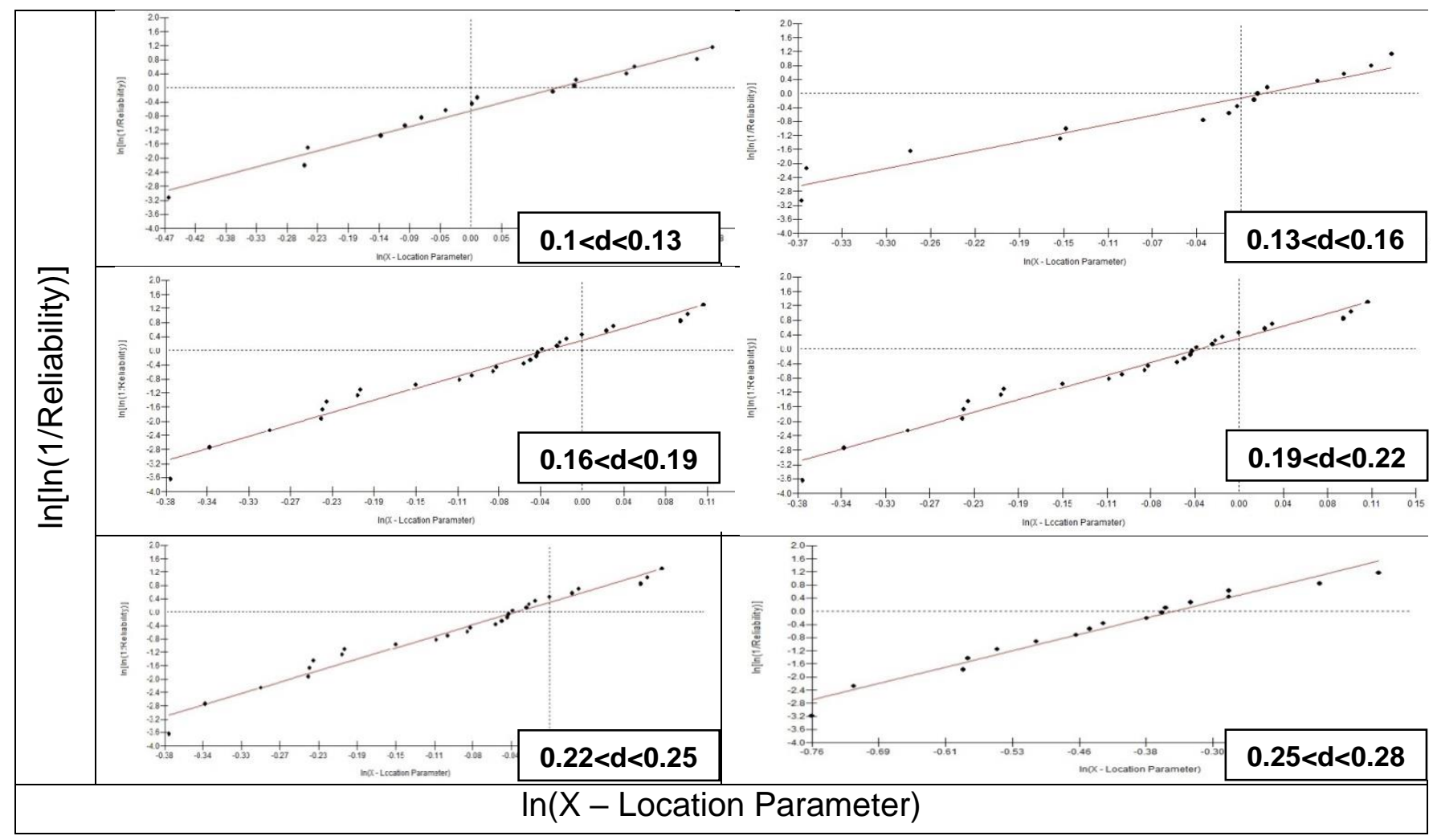

Figure 3. Weibull graphs for the different diameter intervals.

Here it should be noted that not all plots are unimodal, i.e., with just one single straight line fitting the points at each interval. This may indicate distinct behaviors for the density of eucalyptus fibers within the same diameter interval. In spite of this small Weibull discrepancy inside the diameter intervals, only one straight line was assign for each graph. Based in these straight lines, the program provided the corresponding characteristic density $(\boldsymbol{\theta})$, the Weibull modulus $(\boldsymbol{\beta})$ and the precision adjustment $\left(\mathbf{R}^{2}\right)$ parameters. The values of these parameters as well as the average 
density and associated statistical deviations, taking into account the Weibull graphs in Fig. 3, are presented in Tab. 2.

Table 2. Weibull parameters for the density of eucalyptus fibers associated with the different diameter intervals.

\begin{tabular}{|c|c|c|c|c|c|}
\hline $\begin{array}{c}\text { Diameter } \\
\text { interval }(\mathrm{mm})\end{array}$ & $\begin{array}{c}\text { Weibull } \\
\text { Modulus, } \\
\beta\end{array}$ & $\begin{array}{c}\text { Characteristic } \\
\text { density, } \theta \\
\left(\mathrm{g} / \mathrm{cm}^{3}\right)\end{array}$ & $\begin{array}{c}\text { Precison } \\
\text { Adjustment, } \\
\mathbf{R}^{2}\end{array}$ & $\begin{array}{l}\text { Average } \\
\text { density } \\
\left(\mathrm{g} / \mathrm{cm}^{3}\right)\end{array}$ & $\begin{array}{c}\text { Statistical } \\
\text { Deviation } \\
\left(\mathrm{g} / \mathrm{cm}^{3}\right)\end{array}$ \\
\hline $0.10<d<0.13$ & 6.034 & 1.125 & 0.9406 & 1.044 & 0.201 \\
\hline $0.13<d<0.16$ & 6.890 & 1.003 & 0.9301 & 0.938 & 0.160 \\
\hline $0.16<d<0.19$ & 8.995 & 0.966 & 0.9716 & 0.915 & 0.122 \\
\hline $0.19<d<0.22$ & 10.66 & 0.958 & 0.9593 & 0.913 & 0.104 \\
\hline $0.22<d<0.25$ & 7.856 & 0.948 & 0.9352 & 0.892 & 0.135 \\
\hline $0.25<d<0.28$ & 8.298 & 0.732 & 0.9209 & 0.690 & 0.099 \\
\hline
\end{tabular}

The variation of the characteristic density with the average fiber diameter for each one of its intervals is presented in Fig. 4. This figure presents a regular tendency for the $\boldsymbol{\theta}$ parameter to vary with the inverse of the eucalyptus fiber diameter. This means that the density of the eucalyptus fiber holds an inverse correlation with the fiber diameter. This correlation adjusts to a hyperbolic equation of the type:

$$
\theta=\frac{0.059}{d}+0.616
$$

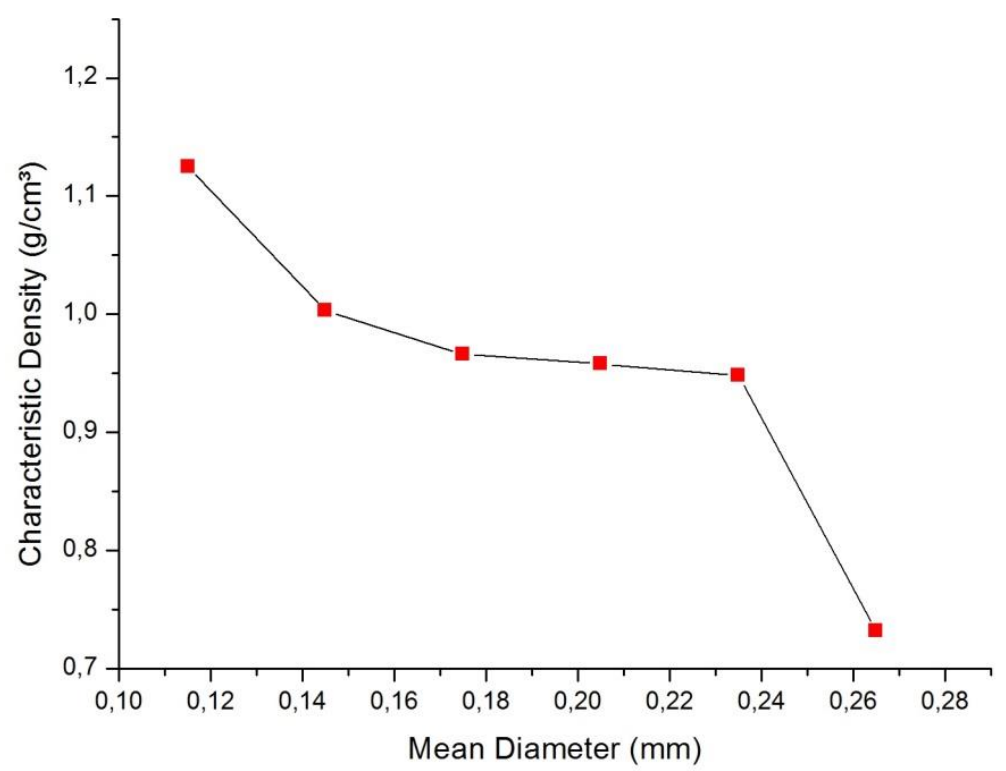

Figure 4. Variation of the eucalyptus characteristic density, $\boldsymbol{\theta}$, from the Weibull analysis with the corresponding diameter.

From the Tab. 2 it is also possible to plot the graphs for the average density against the diameter, shown in Fig. 5. This figure confirms the inverse correlation between the density and the diameter found in Fig. 4. However, the corresponding mathematical adjustment provides the following hyperbolic equation:

$$
\rho_{m}=\frac{0.052}{d}+0.601
$$




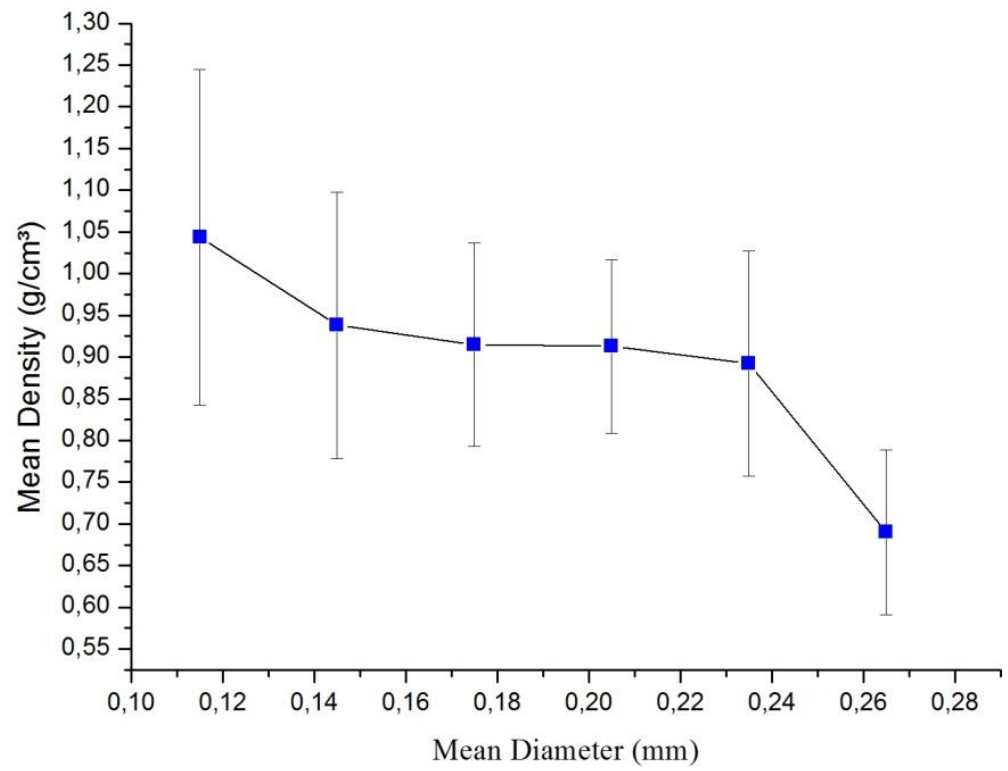

Figure 5. Diameters of the Eucalyptus and their respective average densities.

A comparison between Eq. (B), Fig. 4, and Eq. (C), Fig. 5, indicates a definite tendency for the Eucalyptus density to markedly vary with the inverse of the fiber diameter.

\section{CONCLUSION}

- The analysis of more than 100 fibers of eucalyptus showed an inverse dependence between the density and fiber diameter, so that the larger the diameter the lower the density.

- The Weibull analysis show some inconsistency on the unimodal graphs construction that can be attributed to large dispersion of natural fibers. In eucalyptus fibers, flaws and defects are presented in large quantities, because its structure and composition.

- Statistically, the organized distribution and structure formation for the fibrils creates this kind of mechanism and reaction.

\section{Acknowledgements}

The authors thank the support to this investigation by the Brazilian agencies: $\mathrm{CNPq}$, CAPES, FAPERJ.

\section{REFERÊNCIAS}

1 S. Kalia, B. S. Kaith, I. Kaurs, Cellulose Fibers: Bio - and Nano - Polymer Composites ( New York: Springer, 2011).

2 A. Gore, An Inconvenient Truth. The Planetary Emergency of Global Warming and What We Can do About It (Emmaus, Pennsylvania, USA: Rodale Press, 2006).

3 A.K. Bledzki, J. Gassan, “Composites Reinforced With Cellulose-Based Fibers". Prog. Polym. Sci, 4 (1999) 221-274.

$4 \quad$ D. NabiSahed J.P. Jog, "Natural fiber polymer composites: a review", Advances in Polymer Technol., 18 (1999), 221-274. 
5 A.K. Mohanty, M. Misra and L.T. Drzal, "Sustainable biocomposites from renewable resources: opportunities and challenges in the green material world", J. Polym. Environ., 10 (2002), 19-26

6 Crocker, J., "Natural materials innovative natural composites". Materials Technology, 23 (2008) 174-178

7 S.N. Monteiro, F.P.D. Lopes, A.S. Ferreira, D.C.O. Nascimento, "Natural fiber polymer matrix composites: cheaper, tougher and environmentally friendly", JOM, 61 (2009) 1722.

8 R. Malkapuram, V. Kumar, Y. S. Nezi "Recent development in natural fiber rein forced polypropylene composites" J. Reinforced Plastics and composites; 28 (10)(2009) 11691189.

9 G. Marsh, "Next step for automotive materials". Mater. Today, 6(4) (2003) 36-43.

10 J. Hulbery, D. Houston, "Natural fiber reinforced polymer composites in automotive application", JOM, 58 (2006) 80-86.

11 R. Zah, R. Hischier, A.L. Leão and I. Brown, "Curaua fibers in automobile industry - A sustainability assessment". J. Cleaner Production, 15, (2007) 1032-1040.

12 S. N. Monteiro, K. G. Satyanarayana, F. P. D. Lopes "High strength natural fibers for improred polymer matrix composites" Mat. Sei. Forum 638-642 (2010) 961-966.

13 B.D. Agarwal and L.J. Broutman: Analysis and Performance of Fiber Composites. (New York,NY: John Wiley \& Sons, 1990). 